\title{
OBITUARY
}

\section{Per Björntorp}

Professor Per Björntorp at Gothenburg University, Sweden, died October 10, 2003, at the age of 72, after some time of illness. He leaves his wife, Marianne Björntorp, children and grandchildren.

International Journal of Obesity (2004) 28, 351. doi:10.1038/sj.ijo.0802581

Per Björntorp is dead. An exceptional research career is consequently ended. However, his pioneering work will survive.

Per Björntorp became Professor of Internal Medicine at Sahlgrenska University Hospital, Gothenburg, Sweden in 1977, and was Head of the Department of Internal Medicine until his retirement in 1996.

Per Björntorp was a pioneer in clinical research. He early introduced basic experimental methods in order to solve clinical questions. His interest in metabolism and metabolic control at the cellular level brought him to important clinical problems related to diabetes type II, obesity and cardiovascular disease. Per Björntorp realized the connection between these conditions at an early stage, and was one of the fathers of the metabolic syndrome.

During more recent years, Per Björntorp focused on stressrelated conditions causing interference with the HPA axis, abdominal obesity, insulin resistance and diabetes. In his mapping of these conditions, he also penetrated the underlying genetic, central nervous, hormonal, immunological and metabolic disturbances. His research was thus characterized by breadth as well as by depth.

Per Björntorp's research resulted in a great international reputation. He served as visiting professor at Rockefeller University and Columbia University in New York, and at the University of Barcelona in Spain. He was Editor-in-chief of IJO during the period 1983-1989. Per Björntorp was awarded several international prizes including The Willendorf Prize (1983), The Söderberg's Award (1990), Fellow of the Royal College of Physicians (1991), The Wasserman Award (2000) and The Henry Sebrell Award (2002).

In spite of all credits, Per Björntorp was characterized by a lack of prestige and an unconditional generosity. His door was always open for colleagues asking for his advice.

In addition to science, Per Björntorp had three big interests: music, gastronomy and sailing. His family and friends had numerous occasions to enjoy his culinary skills and he had an extraordinary ability to show hospitality and create a congenial atmosphere around him. Per Björntorp was an amateur cellist and had studied at the Gothenburg Conservatory in the 1950s. He had lessons from several wellknown cellists during all his life; he was extremely interested in chamber music and he played regularly in the Sundbergska association, Jönköping Symphony Orchestra and other music societies.

His friends and colleagues mourn the loss of Per Björntorp, and will remember him with great thankfulness.

Gothenburg, October 26, 2003

L Sjöström

Department of Body Composition and Metabolism, Internal Medicine, Göteborg University, Sahlgrenska University Hospital, Vita Stråket 15, Göteborg SE-41345, Sweden 